\title{
The stoichiometry of inorganic carbon and nutrient removal in the Mississippi River plume and adjacent continental shelf
}

\author{
W.-J. Huang ${ }^{1}$, W.-J. Cai ${ }^{1}$, R. T. Powell ${ }^{2}$, S. E. Lohrenz ${ }^{3}$, Y. Wang ${ }^{1}$, L.-Q. Jiang ${ }^{1,}{ }^{,}$, and C. S.Hopkinson ${ }^{1}$ \\ ${ }^{1}$ Department of Marine Sciences, University of Georgia, Athens, Georgia, 30602, USA \\ ${ }^{2}$ Central Carolina Community College, Sanford, North Carolina, 27330, USA \\ ${ }^{3}$ Department of Fisheries Oceanography, University of Massachusetts Dartmouth, New Bedford, MA 02744, USA \\ * current address: Earth Resources Technology 6100 Frost Place, Suite A Laurel, MD 20707, USA
}

Correspondence to: W.-J. Cai (wcai@uga.edu)

Received: 18 January 2012 - Published in Biogeosciences Discuss.: 6 February 2012

Revised: 27 June 2012 - Accepted: 28 June 2012 - Published: 30 July 2012

\begin{abstract}
The stoichiometry of dissolved inorganic carbon (DIC) and nutrients during biological uptake is widely assumed to follow the Redfield ratios (especially the $\mathrm{C} / \mathrm{N}$ ratio) in large river plume ecosystems. However, this assumption has not been systematically examined and documented, because DIC and nutrients are rarely studied simultaneously in river plume areas and interpretation of ratios can be confounded by strong river-ocean mixing as well as intense biological activity. We examined stoichiometric ratios of DIC and nutrients $\left(\mathrm{NO}_{3}^{-}, \mathrm{PO}_{4}^{3-}\right.$ and $\left.\mathrm{Si}[\mathrm{OH}]_{4}\right)$ in the Mississippi River plume and adjacent continental shelf in June 2003 and August 2004 and calculated biological removal as the difference between observed concentrations and those predicted from conservative mixing, as determined from a multi-endmember mixing model and observed salinity and total alkalinity. Despite complex physical and biogeochemical influences, relationships between DIC and nutrients were strongly dependent on salinity range and geographic location, and influenced by biological removal. Lower $\mathrm{C} / \mathrm{Si}$ and N/Si ratios in one nearshore area were likely due to localized input of high $\mathrm{Si}$ and low $\mathrm{NO}_{3}^{-}$water from adjacent wetlands or preferential removal of nitrogen in the area. When net biological uptake was separated from river-ocean mixing and corrected for preferential $\mathrm{N}$ removal, the stoichiometric ratio of C/N/Si was similar to the Redfield ratio, thus supporting the applicability of the Redfield-type C/N/Si ratios in river-plume biogeochemical models.
\end{abstract}

\section{Introduction}

Large river plumes and surrounding waters are important as processors of terrestrially-derived biogenic elements, such as carbon, nitrogen, phosphorus and silicon, as these materials are transported from land to the ocean. Redfield (1958) first proposed a biological control for a fixed C/N/P stoichiometry of marine plankton, and subsequently inorganic and organic stoichiometry has been examined in freshwater (Hecky et al., 1993), marginal seas (Frigstad et al., 2011; Hupe and Karstensen, 2000), and the open ocean (Anderson and Samiento, 1994; Hopkinson and Vallino, 2005; Li et al., 2000; Li and Peng, 2002). These studies have led to an improved understanding of the relationships between nutrient availability and biogeochemical processes such as photosynthesis and remineralization in all aquatic systems. Redfield stoichiometric ratios have been applied in coastal ocean biogeochemical models in the northern Gulf of Mexico (Fennel et al., 2011; Green et al., 2006, 2008), and used in linking river nutrient loading with sea surface partial pressure of carbon dioxide (Gypens et al., 2004) and ocean acidification (Borges and Gypens, 2010). These studies have widely assumed that the dissolved inorganic carbon (DIC) uptake and nitrogen removal ratio in the water column follows the Redfield value (i.e. 106/16 by atoms). However, to our knowledge, a detailed analysis of field data and thus a field validation of the stoichiometric relationship between DIC uptake and inorganic nitrogen, phosphate and silicate removal are lacking for large river plumes, especially when variability of $\mathrm{C} / \mathrm{N} / \mathrm{P}$ stoichiometry of microalgae and of assimilation has 
been observed (Geider and La Roche, 2002; Donald et al., 2001). This is largely due to the fact that DIC and nutrient removal are rarely reported simultaneously for river plumes, although such information is critical to efforts to characterize factors controlling carbon sinks and sources in these regions.

Intense biological processes have been reported in large river plumes and can include high uptake rates of carbon (Ternon et al., 2000; Cai, 2003) and nutrients (DeMaster and Pope, 1996; Lohrenz et al., 1997). However, DIC and nutrient concentrations in plumes are also affected by temporally variable and spatially heterogeneous river-ocean mixing dynamics, which can complicate the interpretation of the biological signals (as opposed to those within spatially bounded estuaries, Gazeau et al., 2005). In addition, there are extensive intertidal wetlands along the Louisiana coast that are usually neglected in considerations of the Mississippi River loading, which could be significant sources of dissolved nutrients such as $\mathrm{Si}$ (Struyf et al., 2006). This potential Si source could further complicate the relationship between DIC and nutrients in adjacent shelf and river plume waters. Therefore, knowledge of water mixing and elemental exchange between linked river-estuary-plume-shelf systems is critical to fully understanding plume biological dynamics, their relationship to the stoichiometry of $\mathrm{C} / \mathrm{N} / \mathrm{P} / \mathrm{Si}$ uptake, and ultimately the forecasting and management of these systems in a global context.

To examine the stoichiometric ratios of $\mathrm{C} / \mathrm{N} / \mathrm{P} / \mathrm{Si}$ uptake in the Mississippi River plume, we first considered the conservative mixing properties of multiple water masses by using a multi-end-member model. We then calculated biological removal of DIC and inorganic nitrogen, phosphate, and silicate. Additionally, we examined DIC, nutrients, and their biological removal in relationship to geographic setting to discern potential effects of the adjacent coastal wetlands on uptake stoichiometry.

\section{Methods}

\subsection{Site description}

The Mississippi River splits into the Mississippi and the Atchafalaya Rivers before emptying onto the Louisiana shelf. The Atchafalaya River receives about $30 \%$ of the Mississippi River's water (van Heerden et al., 1983) with some additional inputs from a much smaller local river, the Red River. These rivers account for the majority of freshwater inputs to the Louisiana shelf. The average discharge of the Mississippi River was $17300 \mathrm{~m}^{3} \mathrm{~s}^{-1}$ during 24-29 June 2003 and $9000 \mathrm{~m}^{3} \mathrm{~s}^{-1}$ during 9-12 August 2004. River discharge was declining during both periods (Fig. 1). The Barataria estuary is located to the west of the Mississippi River and just to the north of the river plume in the Louisiana Bight (Fig. 2a). Barataria Bay, at the seaward end of the estuary, is a large, brackish water dominated bay with extensive fring-

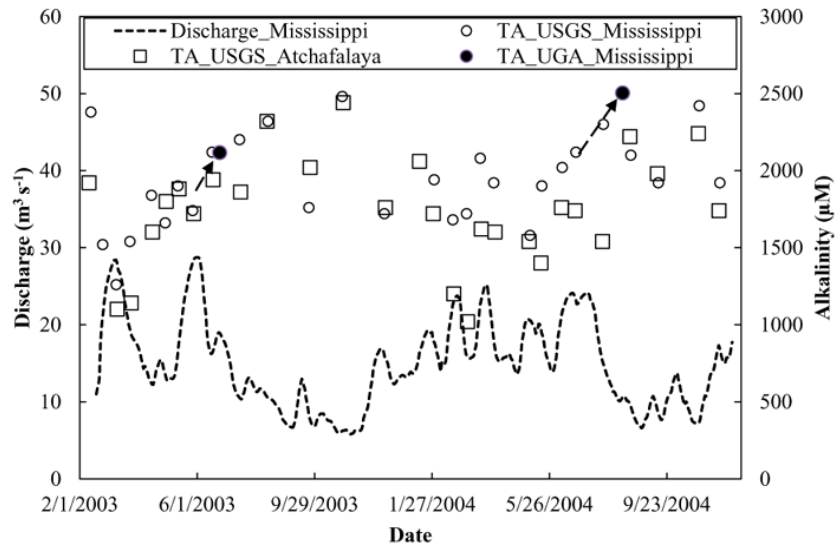

Fig. 1. Temporal variation of the Mississippi River discharge (dashed line) and TA values from the USGS site St. Francisville (site\# 07373420, open circles), from the Mississippi River channel (solid circles, this study), and from the Atchafalaya River at USGS site Melville (site\#07381495, squares). The two dashed arrows indicate increasing rates of TA prior to the cruise periods: $1.7 \mu \mathrm{M} \mathrm{d}^{-1}$ during 12 May to 24 June 2003 (increasing $75 \mu \mathrm{M}$ ) and $6.4 \mu \mathrm{M} \mathrm{d}^{-1}$ during 22 June to 11 August 2004 (increasing $322 \mu \mathrm{M}$ ).

ing salt and brackish marshes. Rainwater is the only source of fresh-water to the estuary except for occasional inputs from the Mississippi River's Davis Pond diversion near its southeast edge $\left(\sim 250 \mathrm{~m}^{3} \mathrm{~s}^{-1}\right.$ when operative). The mean tidal discharge through the passes of Barataria Bay is $\sim 6950 \mathrm{~m}^{3} \mathrm{~s}^{-1}$, equivalent to $43 \%$ of the average discharge of the lower Mississippi River (Das et al., 2010). Such strong tidal exchange also introduces Mississippi River-influenced shelf water into this estuary (Li et al., 2011). The dominant coastal current on the Louisiana shelf generally flows to the west, but a clockwise eddy occurs in the Louisiana Bight adjacent to the northwest of the Mississippi River birdfoot delta (Morey et al., 2003; Walker et al., 2005).

\subsection{Sampling}

Two cruises were conducted on board R/V Pelican in June 2003 and August 2004 in the Louisiana Bight and adjacent shelf. The first cruise focused on the Louisiana Bight region while the second cruise covered a broader area extending towards Texas and including the Atchafalaya plume region. The first cruise followed a lower Mississippi River cruise during 20-24 June 2003 (Dagg et al., 2005). Total alkalinity (TA) and DIC concentrations were determined for water samples collected either from Niskin bottles mounted on a carousel included as part of the vertical profiling package or from the ship's flow-through system from about $1 \mathrm{~m}$ depth via a floating water intake. DIC and TA samples were collected using $120 \mathrm{ml}$ glass bottles thoroughly flushed with sample with extensive overflow ( $>60 \mathrm{ml}$ ). DIC was measured shortly after the cruise by acidifying $0.5 \mathrm{ml}$ of sample 

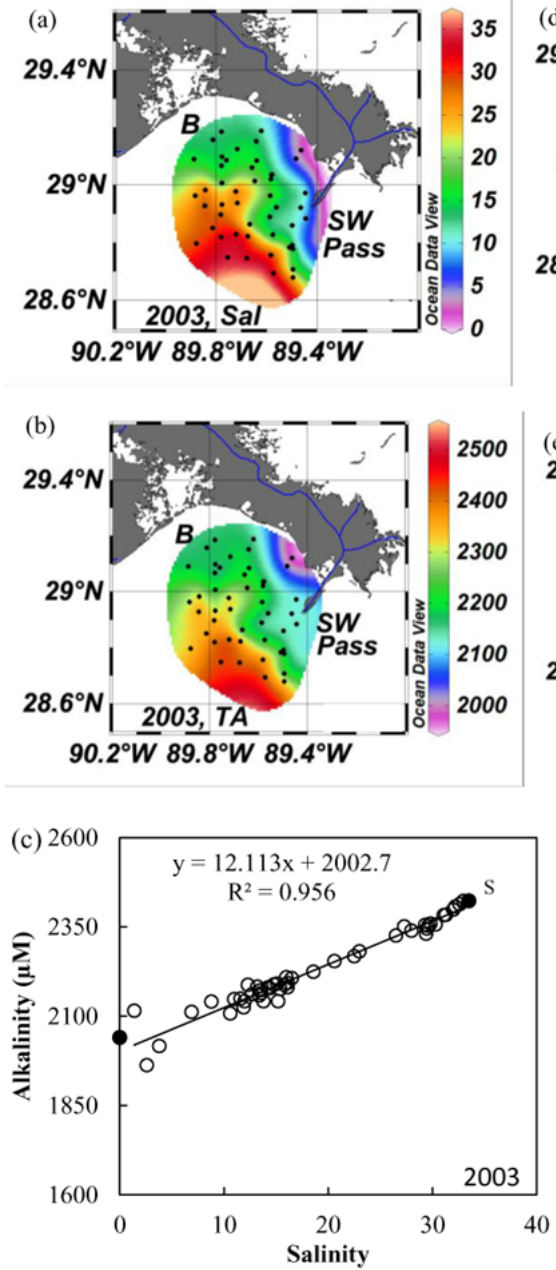
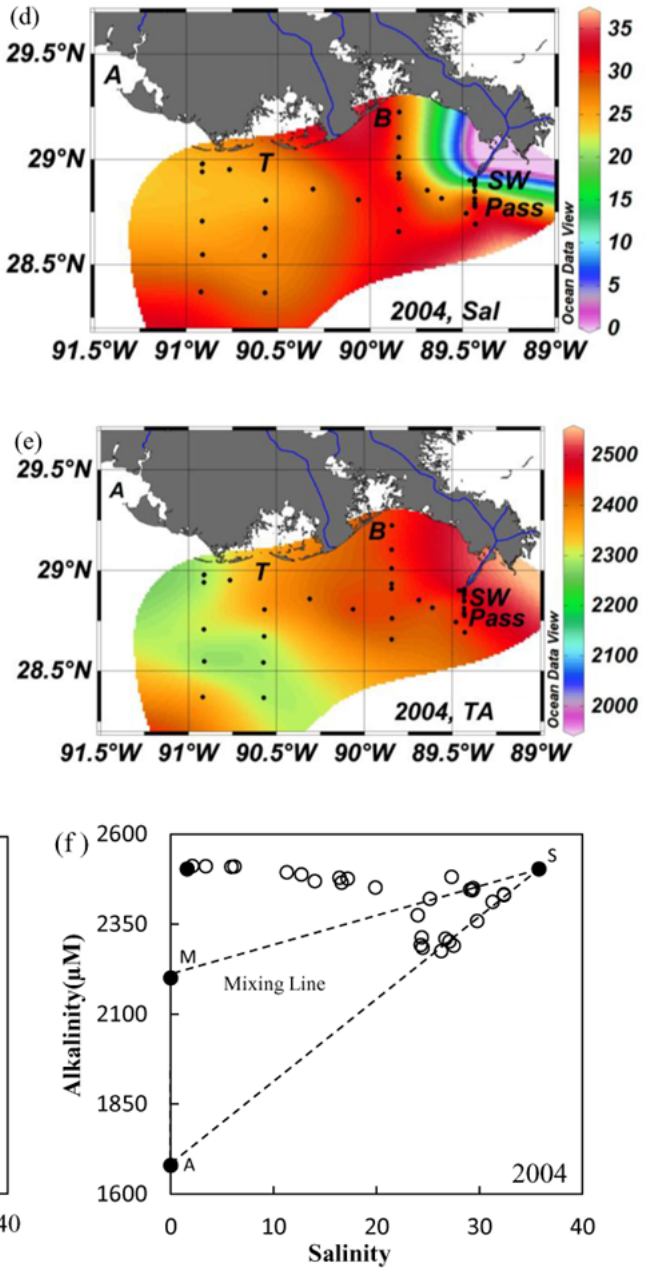

Fig. 2. Spatial distributions of salinity and TA in June 2003 (a and b, respectively) and in August 2004 (d and e, respectively), and relationships between salinity and TA for June 2003 (c) with linear regression line and for August 2004 (f) with conservative mixing lines (dashed lines). "A" represents the Atchafalaya Bay, "T" is the Terrebonne Bay, "B" is the Barataria Bay, and "SW Pass" is the Southwest Pass of the Mississippi River. Black dots on the spatial distribution stand for sampling sites. Black circles in (c, f) are the end-members. The solid line on (c) represents the linear regression line. For (f), "M", " $A$ ", and "S" represent end-members of the Mississippi River, the Atchafalaya River, and seawater, respectively. The relationship between salinity and potential TA $\left(=\mathrm{TA}+\mathrm{NO}_{3}^{-}\right)$was very similar to the relationship between salinity and $\mathrm{TA}$, for $\mathrm{NO}_{3}^{-}$concentration is much lower compared to TA; thus only the latter is shown.

and quantifying the released carbon dioxide using an infrared gas analyzer (LI-COR ${ }^{\circledR}$ 6252). TA was determined by Gran titration on $16 \mathrm{ml}$ of sample using a semi-automated system equipped with Kloehn pumps. DIC and TA measurements had a precision of $0.1 \%$ (Cai et al., 2010; Cai and Wang, 1998) and were directly referenced to Certified Reference Materials for accuracy. Nutrients, including $\mathrm{NO}_{3}^{-}, \mathrm{PO}_{4}^{3-}$, and $\mathrm{Si}(\mathrm{OH})_{4}$ were determined for samples collected from Niskin bottles or from the flow-through system on the first cruise and only from Niskin bottles on the second cruise. Nutrient samples were filtered $(0.2 \mu \mathrm{M})$ on shipboard and frozen for later analysis. Nutrient analyses were performed as described by Dagg et al. (2005).

\subsection{Estimation of stoichiometry}

To examine the stoichiometry of net carbon and nutrient uptake, we applied a three-end-member mixing model to the data of August 2004 (which covered the larger sampling area) and a two-end-member mixing model to June 2003 data (which covered a smaller area). Further justification for the use of the different end-member models is given in Sect. 3.1. Similar approaches have been applied using a two-/three- end-member or an end-member-free model to estimate the Redfield ratio or stoichiometry of remineralization in open ocean waters (Takahashi et al., 1985; Anderson and Sarmiento, 1994; Li and Peng, 2002; Li et al., 2000). A multi-end-member model was used to estimate the Redfield 
Table 1. End-members of the Mississippi River $\left(X_{\mathrm{M}}\right)$, the Atchafalaya River $\left(X_{\mathrm{A}}\right)$, and marine end $\left(X_{\mathrm{S}}\right)$ for DIC, TA and nutrient values in June 2003 and August 2004. Unit: $\mu \mathrm{mol} 1^{-1}$, except salinity. Uncertainties: $0.1 \%$ for TA and DIC, and the detection limits for nutrients are $0.07 \mu \mathrm{M}$ for $\mathrm{NO}_{3}^{-}, 0.07 \mu \mathrm{M}$ for $\mathrm{PO}_{4}^{3-}$, and $0.1 \mu \mathrm{M}$ for $\mathrm{Si}(\mathrm{OH})_{4}$.

\begin{tabular}{llrrrrrr}
\hline Season & End-member & Salinity & $\mathrm{TA}$ & $\mathrm{DIC}$ & $\mathrm{NO}_{3}^{-}$ & $\mathrm{PO}_{4}^{3-}$ & $\mathrm{Si}(\mathrm{OH})_{4}$ \\
\hline Jun-03 & $X_{\mathrm{M}}$ & $0^{1}$ & $2032^{1}$ & $2051^{1}$ & $114.9^{1}$ & $2.0^{1}$ & $97.8^{1}$ \\
Jun-03 & $X_{\mathrm{S}}$ & $33.5^{5}$ & $2422.5^{5}$ & $2068^{5}$ & $0.4^{5}$ & $0.7^{5}$ & $1.6^{5}$ \\
Aug-04 & $X_{\mathrm{A}}$ & $0.1^{2}$ & $1679^{2}$ & $1729^{3}$ & $72.1^{2}$ & $2.4^{2}$ & $103.9^{2}$ \\
Aug-04 & $X_{\mathrm{M}}$ & $0.1^{4}$ & $2200^{4}$ & $2266^{3}$ & $107.1^{4}$ & $3.1^{4}$ & $104.1^{4}$ \\
Aug-04 & $X_{\mathrm{S}}$ & $35.8^{5}$ & $2502.7^{5}$ & $2119.3^{5}$ & $1.2^{5}$ & $1.1^{5}$ & $1.8^{5}$ \\
\hline
\end{tabular}

${ }^{1}$ Cited from the lower Mississippi River cruise (Dagg et al., 2005).

$2 \mathrm{TA}^{2} \mathrm{PO}_{4}^{3-}$ and $\mathrm{Si}(\mathrm{OH})_{4}$ were modeled by discharge $(Q)$ to species' flux relationship (concentration $\times Q$ ), and $\mathrm{NO}_{3}^{-}$ was modeled by nitrate to nitrate flux relationship in 2004 based on the $Q$ on 28 July. $Q$ was adapted from USGS site

Morgan City (site\# 07381600) and species concentrations were adapted from USGS site Melville (site\# 07381495).

${ }^{3}$ Used an empirical equation DIC $=1.03 \times$ TA in the Atchafalaya River and the Mississippi River, based on 2008-2010 measurements (unpublished data).

${ }^{4}$ Average observations on 20 July 2004 and 17 August 2004 at USGS site Belle Chase (site\# 07374525).

${ }^{5}$ Sea end-members were sampled during the cruise.

stoichiometry in the Arabian Sea (Hupe and Karstensen, 2000) to accommodate strong mixing gradients in coastal waters influenced by major freshwater inputs.

The framework for a three-end-member mixing model is that the sum of all fractional end-member inputs is unity (Eq. 1). Since salinity is a conservative tracer in this model, the salinity for a given water parcel can be estimated as the sum of fractional contributions from the various endmembers (Eq. 2). The contribution of precipitation and evaporation to net freshwater balance in the area can be neglected, as its maximum effect was less than $2 \%$ of the river discharge during these two cruises.

$1=f_{\mathrm{S}}+f_{\mathrm{M}}+f_{\mathrm{A}} \quad$ and

$\mathrm{SAL}=f_{\mathrm{S}} \times S_{\mathrm{S}}+f_{\mathrm{M}} \times S_{\mathrm{M}}+f_{\mathrm{A}} \times S_{\mathrm{A}}$

where $f$ and SAL are the abbreviations for fraction and salinity, respectively. On the left hand side of Eq. (2), SAL is the measured salinity value at a specific station. On the right hand side of Eqs. (1) and (2), the subscripts S, M and A designate the end-members of seawater and the Mississippi and the Atchafalaya Rivers, respectively, which are listed in Table 1 .

Similarly, the TA value due to conservative mixing $\left(X_{\text {mix }}\right)$ is the fractional sum of TA from the various end-members (TA values of $X_{\mathrm{S}}, X_{\mathrm{A}}$, and $X_{\mathrm{M}}$ in Table 1).

$X_{\text {mix }}=f_{\mathrm{S}} \times X_{\mathrm{S}}+f_{\mathrm{M}} \times X_{\mathrm{M}}+f_{\mathrm{A}} \times X_{\mathrm{A}}$.

Analogous relationships and corresponding end-members are applied for our nutrient species of interest: $\mathrm{DIC}, \mathrm{NO}_{3}^{-}$, $\mathrm{PO}_{4}^{3-}$ and $\mathrm{Si}(\mathrm{OH})_{4}$. We then calculate the difference between the observed concentration of an element $(X)$ and its predicted conservative concentration $\left(X_{\text {mix }}\right)$ as the biological drawdown or addition $(\Delta X)$, i.e. $\Delta X=X_{\text {mix }}-X$, for DIC $(\triangle \mathrm{DIC})$, nitrate $\left(\Delta \mathrm{NO}_{3}^{-}\right)$, phosphate $\left(\Delta \mathrm{PO}_{4}^{3-}\right)$ and $\mathrm{Si}(\mathrm{OH})_{4}$
$(\Delta \mathrm{Si})$. To determine the value of the three unknown fractional terms, in addition to Eqs. (1) and (2), we use the TA balance as the third equation of mass conservation. One other process that can change TA values in the river plume is the formation of coccolithphores and the precipitation of $\mathrm{CaCO}_{3}$. Although we observed coccoliths when filtering samples collected at some stations during June 2006 in the Mississippi River plume, analysis of $\mathrm{Ca}^{2+}: \mathrm{Na}^{+}$ratios of the particles on the filters from several stations across the salinity gradient suggested that calcification was not of sufficient magnitude to alter the TA to salinity relationship (W.-J. Cai, unpublished). In addition, $\mathrm{CaCO}_{3}$ saturation statuses calculated from $\mathrm{pH}$ and DIC were much higher than 1 in this plume (Guo et al., 2012), showing that it was unnecessary to consider dissolution of carbonate minerals. However, TA will increase by one unit for every one unit decrease resulting from the biological drawdown of $\mathrm{NO}_{3}^{-}$, i.e. $\Delta \mathrm{TA}=-\Delta \mathrm{NO}_{3}^{-}$ (Brewer and Goldman, 1976; Wolf-Gladrow et al., 2007). Riverine nitrite and ammonium concentrations are only 1$3 \%$ of riverine $\mathrm{NO}_{3}^{-}$concentration and can be neglected in this study. A combination of the conservative mixing and the biological drawdown of TA can be expressed as:

$\mathrm{TA}=f_{\mathrm{S}} \times \mathrm{TA}_{\mathrm{S}}+f_{\mathrm{M}} \times \mathrm{TA}_{\mathrm{M}}+f_{\mathrm{A}} \times \mathrm{TA}_{\mathrm{A}}+\Delta \mathrm{NO}_{3}^{-}$.

Based on Eq. (3) the biological drawdown of $\Delta \mathrm{NO}_{3}^{-}$can be expressed as:

$$
\begin{aligned}
\Delta \mathrm{NO}_{3}^{-}=X_{\mathrm{mix}}-X & =f_{\mathrm{S}} \times \mathrm{NO}_{3 \mathrm{~S}}^{-}+f_{\mathrm{M}} \times \mathrm{NO}_{3 \mathrm{M}}^{-} \\
& +f_{\mathrm{A}} \times \mathrm{NO}_{3 \mathrm{~A}}^{-}-\mathrm{NO}_{3}^{-}
\end{aligned}
$$

By replacing the $\triangle \mathrm{NO}_{3}^{-}$in Eq. (4) with Eq. (5), we have

$$
\begin{aligned}
\mathrm{TA}+\mathrm{NO}_{3}^{-}=f_{\mathrm{S}} & \times\left(\mathrm{TA}_{\mathrm{S}}+\mathrm{NO}_{3 \mathrm{~S}}^{-}\right)+f_{\mathrm{M}} \\
& \times\left(\mathrm{TA}_{\mathrm{M}}+\mathrm{NO}_{3 \mathrm{M}}^{-}\right)+f_{\mathrm{A}} \times\left(\mathrm{TA}_{\mathrm{A}}+\mathrm{NO}_{3 \mathrm{~A}}^{-}\right)
\end{aligned}
$$

We can infer that the potential alkalinity $\left(\mathrm{TA}+\mathrm{NO}_{3}^{-}\right)$is a conservative tracer in addition to salinity (Bates et al., 1998; 
Brewer and Goldman, 1976). However, it is important to recognize that in coastal waters $\mathrm{NO}_{3}^{-}$concentration changes associated with water mass mixing do not contribute to TA; only the part associated with the biological use or release of $\mathrm{NO}_{3}^{-}$contributes.

Thus, for any paired observations of $\mathrm{SAL}_{i}$ and $\left(\mathrm{TA}+\mathrm{NO}_{3}^{-}\right)_{i}$, we can derive $f_{\mathrm{Si}}, f_{\mathrm{Mi}}$, and $f_{\mathrm{Ai}}$ by Eqs. (1), (2) and (6) and derive $X_{\mathrm{mix}}$ and $\Delta X$ for other species thereafter. A non-negative least square solver (Lawson and Hanson, 1974) in the Matlab ${ }^{\circledR}$ software package was adapted to solve the equations. Because there were uncertainties in both " $x$ " and " $y$ " variables, a Type II linear regression, or the major axis method (York, 1966), was used to calculate the ratios of slopes for $\triangle \mathrm{DIC}$ to $\Delta \mathrm{NO}_{3}^{-}, \Delta \mathrm{DIC}$ to $\Delta \mathrm{PO}_{4}^{3-}$, and $\triangle \mathrm{DIC}$ to $\Delta \mathrm{Si}$.

Additionally, the biological removal rates were calculated by dividing $\triangle$ DIC by the plume water residence time (Cai, 2003). Plume water residence time was estimated as $1,1.5,6$ and 6 days for salinities $0-18,18-27,27-32$, and $32-34.5$, respectively based on satellite-derived suspended sediment distributions collected during 1989-1997 (Green et al., 2006).

\section{Results and discussion}

\subsection{Mixing schemes based on salinity and total alkalinity}

Patterns of salinity and TA distribution were used to examine the mixing of freshwater and seawater in the Mississippi River plume. In June 2003, there was a strong salinity gradient across the Louisiana Bight attributable to Mississippi River discharge and the coastal circulation patterns (Fig. 2a). Salinity was lower closer to land and towards the northeast and higher towards the southwest. The TA distribution (Fig. 2b) was very similar to salinity distribution, consistent with the dominating influence by the Mississippi River in the region studied. As such, we used a two-end-member mixing model - Mississippi River and seawater. This two-endmember mixing model is robust because of the strong linear correlation between TA and salinity for this period and region of study (Fig. 2c). A two-end-member mixing is a special case of the three-end-member mixing when one of the endmembers can be neglected or two of the three end-members have similar property values. Therefore, $X_{\text {mix }}$ and $\Delta X$ in June 2003 can be solved by setting $f_{\mathrm{A}}$ as zero in Eqs. (1), (2), and (6). The river end-member was also relatively stable, as the river end-member TA value increased only about $1.7 \mu \mathrm{M} \mathrm{d}^{-1}$ during 43 days prior to the 24 June 2003 cruise (Fig. 1).

The salinity pattern was quite different in August 2004 with low salinity confined to the area immediately adjacent to Southwest Pass (Fig. 2d). Salinity increased with distance from the riverine freshwater sources. Distributions of TA were characterized by higher values close to Southwest Pass and the Atchafalaya Bay (Fig. 2e). An examination of TA versus salinity relationships revealed multiple end-members with strong contributions from the Mississippi, Atchafalaya and seawater for this period (Fig. 2f). A three-end-member mixing model was therefore applied to data (which equated to salinities greater than 24) as we did not collect nutrient samples from the freshest waters, which were confined to immediately adjacent to the river mouth. In addition, as the riverine TA end-member was increasing rapidly during the period before the cruise $\left(\sim 6.4 \mu \mathrm{Md}^{-1}\right.$, Fig. 1$)$, it was necessary to adjust end-member values to account for this increase. Therefore, as the freshwater residence times were on the order of 8.5 days to reach a salinity range of 27-32 (Green et al., 2006), we chose river TA values as the end-members close to 8.5 days before the cruise for the Mississippi and Atchafalaya Rivers (Table 1). The uncertainties introduced by the water residence time are considered in Sect. 3.4. By applying these appropriate river end-member values (USGS data, Table 1), the TA values for salinities greater than 24 were generally within the three-end-member mixing trajectory and thus were taken to be conservative (Fig. 2f). On the other hand, high TA values for salinities less than 24 were viewed as the result of the dramatic increase in the river endmember TA in the days prior to the cruise (Fig. 2f).

\subsection{Mixing pattern vs. biological removal intensity in various locations}

DIC and nutrients in both cruises showed non-linear relationships with salinity (Fig. 3), reflecting mixing and biological processes, which is consistent with previous studies (Cai, 2003; Dagg et al., 2007). For the June 2003 dataset, maximum biological nutrient and DIC uptake were observed at salinities between 10 and 16 (Fig. 3a). This early removal was possibly due to a bloom seeded by freshwater diatoms (Dagg et al., 2008), and was different from our observations made on a dozen other cruises between 2003 and 2011, where maximum biological removal was observed at salinities above 18 (Cai, 2003; Guo et al., 2012; W.-J. Cai, unpublished data). For example, DIC values deviated greatly from the mixing lines when salinity was higher than 24 in August 2004 (Fig. 3c). Such different patterns of mixing versus non-conservative biological removal were also evident in nutrient-salinity plots (Fig. 3).

Relationships between DIC and nutrients also reflected both mixing and biological processes (Fig. 4). Mixing patterns were examined for their corresponding sample locations to identify regional differences in biological removal. In June 2003, $\mathrm{DIC}, \mathrm{NO}_{3}^{-}, \mathrm{PO}_{4}^{3-}$ and $\mathrm{Si}(\mathrm{OH})_{4}$ concentrations deviated from the conservative mixing line and approached the biological uptake line (Fig. 4a-d) for stations with surface salinities less than 24 (northeastern Louisiana Bight, Fig. 4e), suggesting strong biological removal ( $\Delta X$ in Fig. $4 \mathrm{f}-\mathrm{h})$. The regions corresponding to strong removal of DIC and nutrients coincided with regions with high Chl-a and DOC 

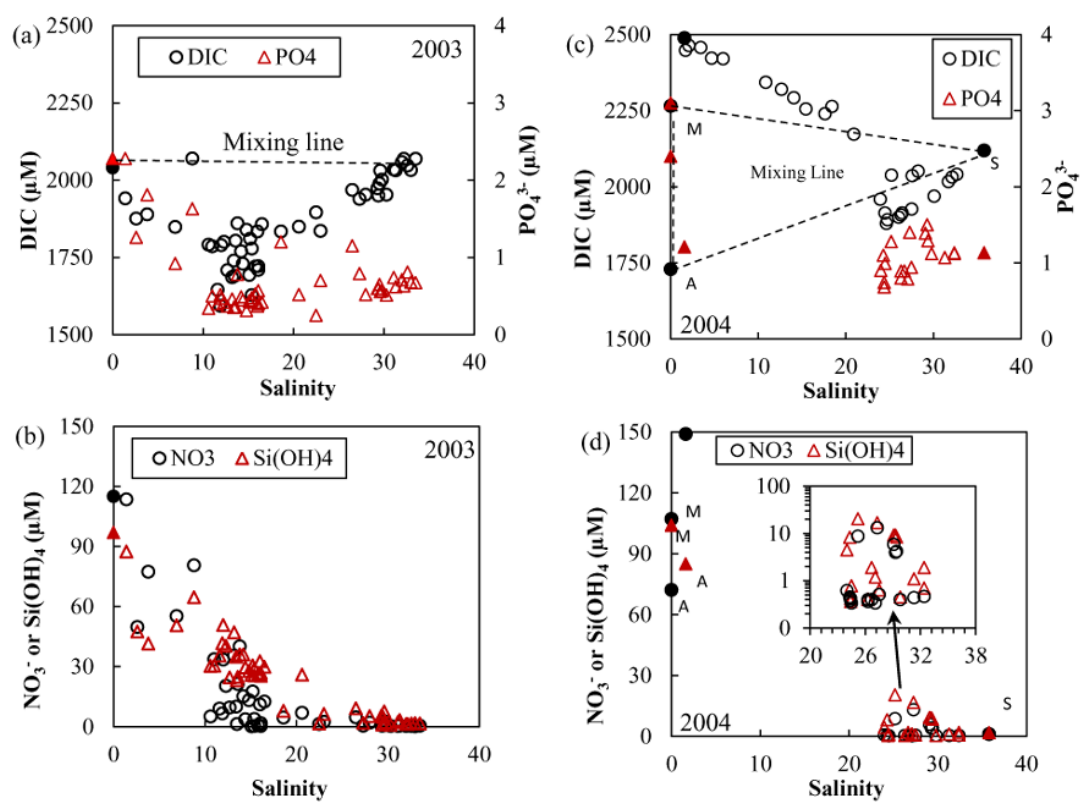

Fig. 3. Variation of DIC and nutrient concentrations along the salinity gradient. DIC versus salinity, and $\mathrm{PO}_{4}^{3-}$ versus salinity (a); $\mathrm{NO}_{3}^{-}$ versus salinity and $\mathrm{Si}(\mathrm{OH})_{4}$ versus salinity (b) for June 2003. DIC versus salinity and $\mathrm{PO}_{4}^{3-}$ versus salinity (c); $\mathrm{NO}_{3}^{-}$versus salinity and $\mathrm{Si}(\mathrm{OH})_{4}$ versus salinity (d) for August 2004. End-members (solid circles) with abbreviations, "M", "A", and "S" in (c) and (d) are as those in Fig. 2f. Conservative mixing lines (dashed lines) are shown for DIC versus salinity in (a) and (c). The inserted figure on (d) enlarges the crowded area with logarithm scale in y-axis. Nutrient data for waters with salinity less than 24 were unavailable in August 2004.

concentrations, consistent with high biological production, as reported previously (Dagg et al., 2008). In contrast, DIC, $\mathrm{NO}_{3}^{-}, \mathrm{PO}_{4}^{3-}$ and $\mathrm{Si}(\mathrm{OH})_{4}$ concentrations were closer to the conservative mixing line (Fig. $4 \mathrm{a}-\mathrm{d}$ ) on the southwestern Louisiana Bight (Fig. 4e, blue squares) where salinities were greater than 24, showing less influence of biological removal (Fig. 4f-h).

In August 2004, there was less deviation from mixing for all elements compared to June 2003 over the Louisiana Bight (Fig. 5a-e), suggesting less intense biological production and nutrient removal (Fig. 5f-h). For low salinity waters proximal to the river mouth, nutrient data were lacking and so it was not possible to calculate net uptake or stoichiometry. These results show that patterns between DIC and nutrients were affected by salinity, sampling location, and strength of biological removal.

\subsection{Stoichiometry}

In considering the stoichiometric uptake of DIC and nutrients, it is important to recognize that DIC uptake and nutrient removal as determined in this study (i.e. by subtracting concentrations estimated for conservative mixing alone) reflect the net effect of autotrophy plus heterotrophy. The concept of varying source terms that differ in stoichiometry was reported by Frigstad et al. (2011), who found that the average $\mathrm{C} / \mathrm{N}$ ratio of suspended particulate organic material (POM) in the Norwegian shelf was the combined result of that due to autotrophs and heterotrophs (the former being higher than Redfield). Differences in uptake by various biological communities may explain observed temporal and spatial differences in stoichiometry (Pahlow and Riebesell, 2000; Li et al., 2000; Li and Peng, 2002). For example, C/ N remineralization ratios of 5.48 were reported in the Atlantic Ocean (Li et al., 2000) compared to $4.6 \pm 0.6$ between latitudes $45-5^{\circ} \mathrm{N}$ (Li and Peng, 2002). Despite the fact that several factors can affect the $\triangle \mathrm{DIC}: \Delta \mathrm{NO}_{3}^{-}$relationships, it is notable that results reported for this study (Table 2) were surprisingly close to the Redfield C/ N ratio and comparable to previously reported remineralization values. This result implies that the net effect of autotrophy and heterotrophy on net biological uptake stoichiometry was close to the Redfield ratio in the Mississippi River plume.

We observed large deviations from the Redfield ratio for $\triangle \mathrm{DIC}: \Delta \mathrm{PO}_{4}^{3-}$ and $\triangle \mathrm{DIC}: \Delta \mathrm{Si}$ (Table 2). Higher slopes of $\triangle \mathrm{DIC}$ to $\Delta \mathrm{PO}_{4}^{3-}$ could have resulted from utilization of organic phosphorus, an argument supported by observations of high alkaline phosphatase activities in the plume (Ammerman and Glover, 2000; Sylvan et al., 2007), and could also be attributed to dissolved inorganic phosphorus released from suspended particulates (Chambers et al., 1995). These two explanations were also probable reasons for the relatively high $\mathrm{PO}_{4}^{3-}$ concentration $(3.6 \mu \mathrm{M})$ measured at the station $\sim 30 \mathrm{~km}$ south of the Mississippi River channel in August 2004. Since this value was higher than the end-members, this 


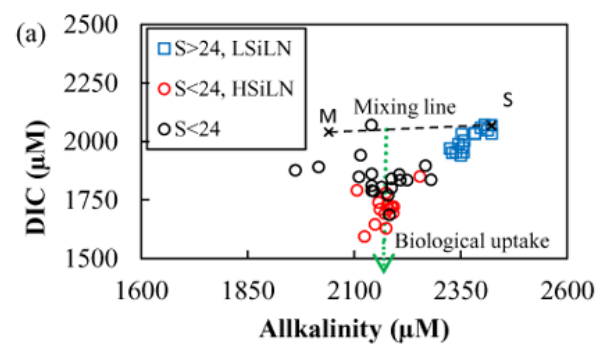

(e)
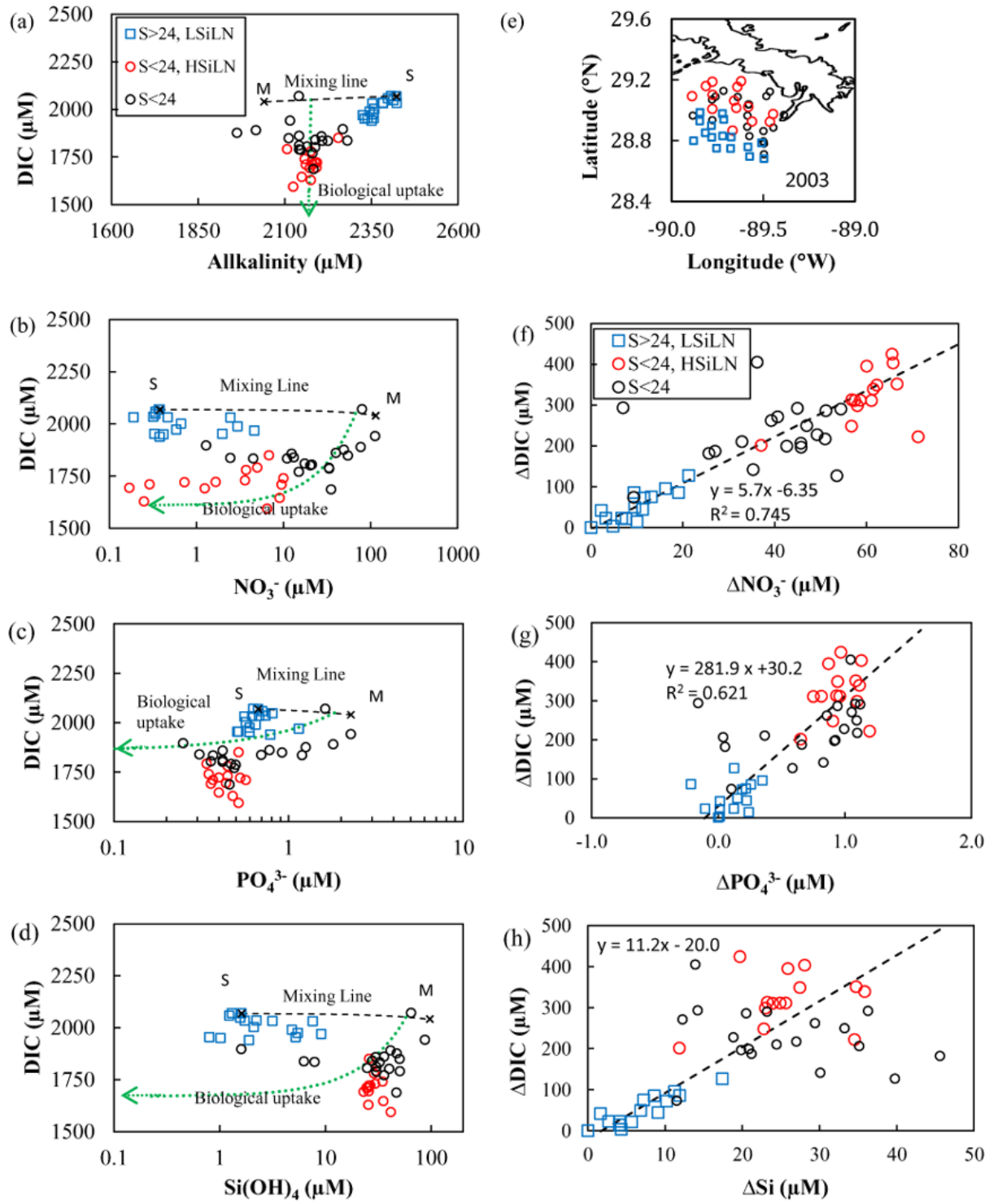

Fig. 4. Relationships between DIC and nutrients, between $\Delta \mathrm{DIC}$ and $\Delta$ nutrients, and their sampling geographic locations for June 2003. Panels (a) to (d) show relationships of DIC to alkalinity, $\mathrm{NO}_{3}^{-}, \mathrm{PO}_{4}^{3-}$, and $\mathrm{Si}(\mathrm{OH})_{4}$, respectively, with conservative mixing lines (black dashed lines) and Redfield-type biological removal lines (green dashed lines). " $X$ " markers with abbreviations " $M$ ", " $A$ ", and " $S$ " are the same end-members as in Fig. 3. For salinity higher than 24, Low Silicate and Low Nitrogen (LSiLN) data were on the southwestern Louisiana Bight, and for salinity less than 24 data ("S $<24$ "), High Silicate and Low Nitrogen (HSiLN) data were on the northeastern Louisiana Bight (e). Panels (f) to (h) show relationships of $\Delta \mathrm{DIC}$ to $\Delta \mathrm{NO}_{3}^{-}, \Delta \mathrm{PO}_{4}^{3-}$, and $\Delta \mathrm{Si}$, respectively, with their correlation lines (dashed lines). All panels share the same legends as in $(\mathbf{a}, \mathbf{f})$.

Table 2. Stoichiometry of DIC uptake and nutrient removals and their correlation coefficients $\left(R^{2}\right)$.

\begin{tabular}{lrrrrrr}
\hline & $\Delta \mathrm{DIC} / \Delta \mathrm{NO}_{3}^{-}$ & \multicolumn{1}{c}{$\Delta \mathrm{DIC} / \Delta \mathrm{PO}_{4}^{3-}$} & $\Delta \mathrm{DIC} / \Delta \mathrm{Si}$ & $\Delta \mathrm{Si} / \Delta \mathrm{NO}_{3}^{-}$ & $\Delta \mathrm{NO}_{3}^{-} / \Delta \mathrm{PO}_{4}^{3-}$ & $\mathrm{C} / \mathrm{Si} / \mathrm{N} / \mathrm{P}$ \\
\hline Jun 03 & $5.7 \pm 0.3$ & $281.9 \pm 21.3$ & $11.2 \pm 1.1$ & $0.5 \pm 0.1$ & $49.8 \pm 2.9$ & $91 \pm 5 / 8.0 \pm 1.6 / 16 / 0.3 \pm 0.2$ \\
$R^{2}$ & 0.745 & 0.621 & 0.416 & 0.588 & 0.773 & \\
Aug 04 & $5.0 \pm 1.1$ & $135.3 \pm 18.6$ & $4.1 \pm 0.8$ & $1.2 \pm 0.4$ & $25.9 \pm 4.4$ & $80 \pm 18 / 19 \pm 6 / 16 / 0.6 \pm 0.3$ \\
$R^{2}$ & 0.875 & 0.578 & 0.443 & 0.733 & 0.644 & \\
\hline
\end{tabular}



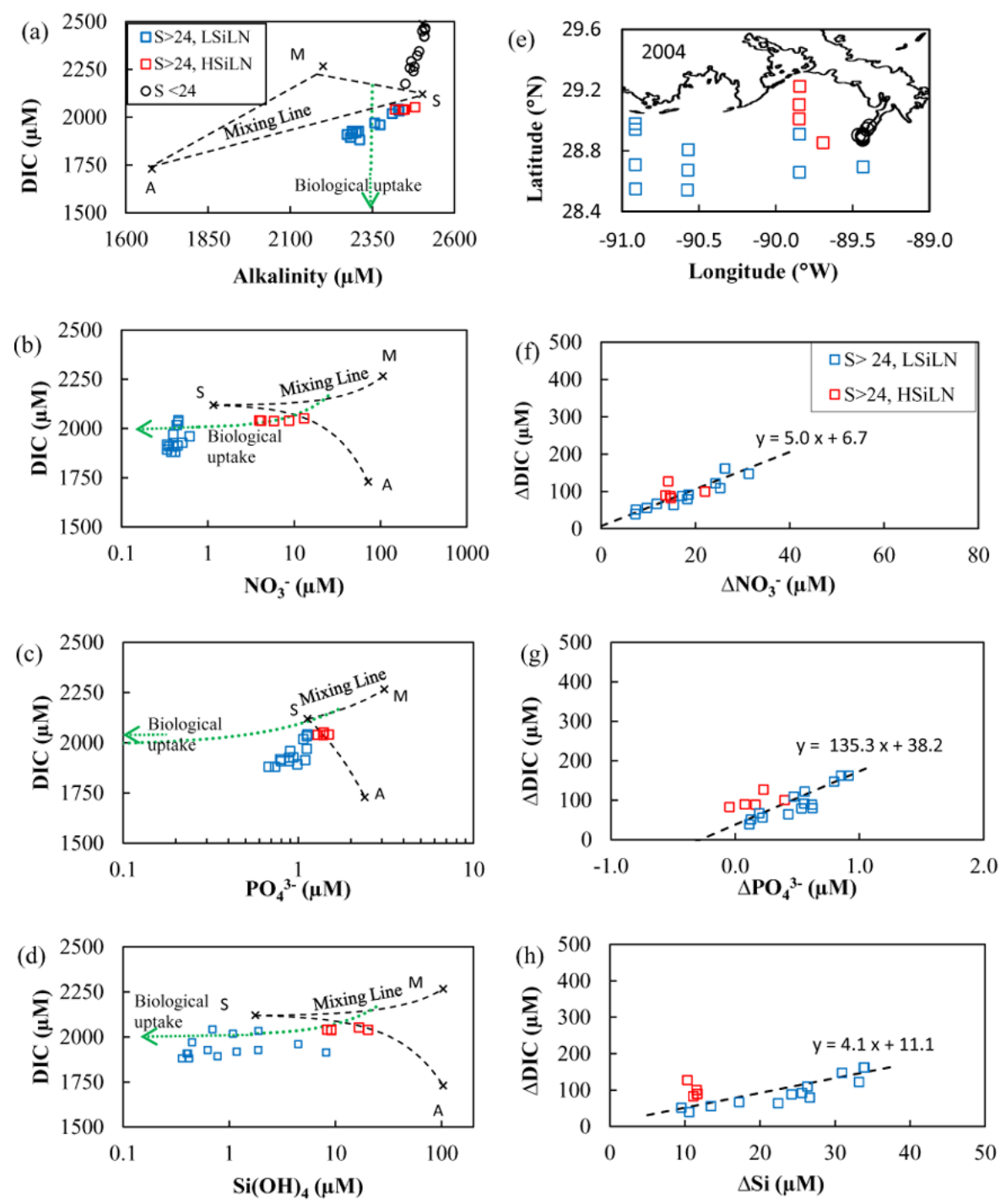

Fig. 5. Relationships between DIC and nutrients, between $\Delta$ DIC and $\Delta$ nutrients, and their sampling geographic locations for August 2004. Panels (a) to (d) show relationships of DIC and alkalinity, and of DIC and nutrients, with conservative mixing lines (black dashed lines) and Redfield-type biological removal lines (green dashed lines). " $X$ " markers with abbreviations "M", "A", and "S" are the same end-members as in Fig. 3. For salinity higher than 24, LSiLN data were on the southwestern Louisiana Bight and the adjacent shelf, and for salinity higher than 24, HSiLN data were on the northeastern Louisiana Bight (e). Salinity less than 24 data were near the Mississippi River mouth. Panels (f) to (h) show relationships of $\triangle \mathrm{DIC}$ and $\Delta$ nutrients with correlation lines (dashed lines). All panels share the same legends as in (a, f).

value was not included in the $\Delta \mathrm{PO}_{4}^{3-}$ calculation. We noticed that slopes of $\triangle \mathrm{DIC}$ to $\triangle \mathrm{PO}_{4}^{3-}$ differed substantially between these two cruises, and this may due to differences in relative rates of remineralization and uptake during the two cruises (for example, as was recently reported in the Norwegian shelf, Frigstad et al., 2011). Given the potential contributions of other $\mathrm{PO}_{4}^{3-}$ sources in addition to those sources that were also likely DIC sources, it is acknowledged that using riverine phosphate input to estimate the carbon uptake in the plume area may result in a bias.

Carbon and silicate uptake also varied greatly between these two cruises, but this is to be expected with variations in phytoplankton community structure, which are likely to occur during spring to summer conditions, and with decreased productivity. We found that the slope of $\triangle \mathrm{DIC}$ versus $\Delta \mathrm{Si}$ in August 2004 (4.1 \pm 0.8$)$ was different from that in June 2003 $(11.2 \pm 1.1$, Table 2) and also noticed that the slope of $\Delta \mathrm{Si}$ versus $\Delta \mathrm{NO}_{3}^{-}$was $0.50 \pm 0.1$ in June 2003 and was $1.2 \pm 0.4$ in August 2004 (Table 2). Further explanations for the differences in the slopes of $\Delta \mathrm{DIC}$ versus $\Delta \mathrm{Si}$, and $\Delta \mathrm{Si}$ versus $\Delta \mathrm{NO}_{3}^{-}$are discussed in Sect. 3.6. 


\subsection{Impacts of river end-members and plume residence time on stoichiometry assessments}

The change in the river end-member TA value could also influence the accuracy of the mixing model, which assumes constant end-members. River end-member concentrations generally depend on river discharge. For example, TA values increase with decreasing discharge (Cai et al., 2008) in the Mississippi (Cai, 2003, Fig. 1) and Atchafalaya Rivers, e.g. TA increased $1.7 \mu \mathrm{Md}^{-1}$ before the first cruise and TA increased $6.4 \mu \mathrm{Md}^{-1}$ before the second cruise (Fig. 1). Therefore, as the river end-member varies, the appropriate river end-member for a parcel of plume water would depend on the corresponding water residence time. Thus, the uncertainties of water residence times propagate to the uncertainties of the river end-member. For instance, if we assume an uncertainty of 1 day for the water residence time, this leads to a propagated uncertainty in TA of $4-14 \mu \mathrm{M}$ for the river end-members, assuming the TA river end-member increases 2-7 $\mu \mathrm{M} \mathrm{d}^{-1}$. Additionally, the relationship between nutrient concentrations and river discharge differs from nutrient to nutrient (Lohrenz et al., 1999), e.g. phosphate concentrations in the Mississippi River have been reported to slightly increase with decreasing discharge $(0.1 \mu \mathrm{M}$ over the same period), while nitrate and silicate concentrations were found to decrease $\left(\sim 0.6, \sim 1 \mu \mathrm{M} \mathrm{d}^{-1}\right.$, respectively). Therefore, the uncertainties of the multi-end-member model depend on the uncertainties of water residence time and variation of river end-members. However, we argue that our estimates of biological removal are robust because (1) the river end-member was relatively stable in June 2003 , reflected by the good linear correlation between salinity and TA, and (2) a $10 \%$ variation in the river end-member on 15 August 2004 would result in only a $0.1 \%$ change in estimated values for salinities larger than 24 .

\subsection{Rates of biological removal}

Results showed that biological removal rates crested in middle salinity waters and decreased toward higher salinity. In June 2003, non-conservative uptake deviations for $\Delta$ DIC were upper to $450 \mu \mathrm{M}$ for salinities less than 27 and were less than $130 \mu \mathrm{M}$ for salinities greater than 27 . The corresponding rates of DIC removals were upper to $2.2 \mathrm{~g} \mathrm{C} \mathrm{m}^{-3} \mathrm{~d}^{-1}$ for salinities less than 27 and $0-0.18 \mathrm{~g} \mathrm{C} \mathrm{m}^{-3} \mathrm{~d}^{-1}$ for salinities higher than 27 (over 2.5 and 8.5-14.5 days, respectively). In August 2004, DIC removal rates were 0.38$0.78 \mathrm{~g} \mathrm{C} \mathrm{m}^{-3} \mathrm{~d}^{-1}$ for salinities less than 27 and $0.03-$ $0.18 \mathrm{~g} \mathrm{C} \mathrm{m}^{-3} \mathrm{~d}^{-1}$ for salinities greater than 27 . These DIC removal rates were comparable to those reported by Cai (2003) of $1.5-3 \mathrm{~g} \mathrm{C} \mathrm{m}^{-3} \mathrm{~d}^{-1}$ for August and September 1998. When compared to the study using the same water residence time (Green et al., 2006), our estimates of DIC removal rates were slightly higher than theirs for salinities less than 27 (0.102$0.818 \mathrm{~g} \mathrm{C} \mathrm{m}^{-3} \mathrm{~d}^{-1}$ ), and were comparable to theirs for salin- ities higher than $27\left(0.120-0.491 \mathrm{~g} \mathrm{C} \mathrm{m}^{-3} \mathrm{~d}^{-1}\right)$. Such higher observed rates for salinities less than 27 in June 2003 may be due to the fact that the plume appeared to be very productive (cf. Dagg et al., 2008). Similarly, primary production rates $\left(1-5 \mathrm{~g} \mathrm{C} \mathrm{m}^{-3} \mathrm{~d}^{-1}\right)$ estimated by the ${ }^{14} \mathrm{C}$ incubation method also showed a maximum in the mid salinity waters (Redalje and Fahnenstiel, 1994; Lohrenz et al., 1990; Dagg and Breed, 2003), again consistent with our estimates of maxima DIC removal. Furthermore, as the uncertainties mentioned in Sect. 3.4 also affect the estimated biological removals results, we have more confidence in the mid- to high- salinity biological removal because of less sensitivity to the water residence uncertainties. Despite the larger water residence time uncertainties for our estimates of biological removal at low salinities, our estimated removal rates were still on the same order of magnitude as previous studies.

\subsection{Silicate removal and $\mathrm{Si}-\mathrm{N}$ relationships}

Correlations of $\triangle \mathrm{DIC}: \Delta \mathrm{NO}_{3}^{-}$were fairly high $\left(R^{2}>0.745\right)$, but the correlations of $\Delta \mathrm{DIC}: \Delta \mathrm{Si}$ were much lower $\left(R^{2}<0.443\right)$ (in Table 2). To further explore the weak correlations between $\triangle \mathrm{DIC}$ and $\Delta \mathrm{Si}$, we compared the observed values of $\mathrm{Si}(\mathrm{OH})_{4}$ and $\mathrm{NO}_{3}^{-}$in relationship to sampling locations. We found that the relationships between $\mathrm{Si}(\mathrm{OH})_{4}$ and $\mathrm{NO}_{3}^{-}$were strongly dependent on locations (Fig. 6a and b), which is consistent with the observed variations in relationships between DIC and nutrients as described in Sect. 3.2 (Figs. 4 and 5). A relationship of high silicate concentration $(>2 \mu \mathrm{M})$ relative to low nitrate concentration $(<10 \mu \mathrm{M}$, hereafter referred to as HSiLN) was observed for the northeastern Louisiana Bight in June 2003 (Figs. 6a, 4e, 3b) where biological DIC removal was particularly high (Figs. 3a, 4f and g). In contrast, low concentrations of silicate and nitrate (hereafter referred to as LSiLN) were found in the southwestern Louisiana Bight (Figs. 6a, 4e) where biological DIC removal was relatively low (Figs. 3a, 4f and g). A similar spatial dependency in nutrient relationships was observed in August 2004 (Figs. 6b and 5e). If we only consider the LSiLN area with salinities greater than 24 (Fig. 6c and d), the slope of the $\Delta \mathrm{Si}$ versus $\Delta \mathrm{NO}_{3}^{-}$relationship was $0.7 \pm 0.1$ in June 2003 and was $1.1 \pm 0.2$ in August 2004. These slopes are comparable to relationships reported in a previous study ( 0.8 , Fisher et al., 1988) and close to the Redfield $\mathrm{Si} / \mathrm{N}$ ratio of one (Redfield, 1958; Brzezinski, 1985). Because $\Delta \mathrm{Si}$ was lower than expected if removal were due to equivalent uptake of both silicate and nitrate, such as uptake of a diatom community (Brzezinski, 1985), we infer an additional source term for high silicate and low $\mathrm{NO}_{3}^{-}$or a preferential removal of nitrogen over silicate in this highly productive area (Fig. 6c and d). 

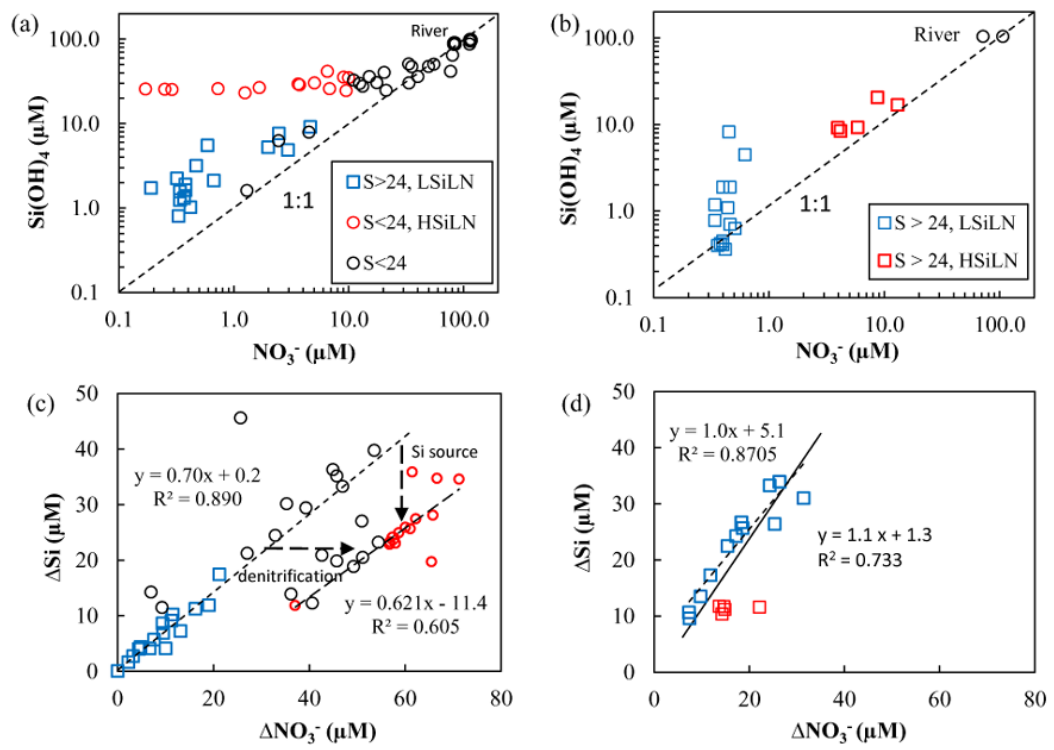

Fig. 6. Relationships between $\mathrm{Si}(\mathrm{OH})_{4}$ versus $\mathrm{NO}_{3}^{-}$for June 2003 (a) and for August 2004 (b), and between $\Delta \mathrm{Si}$ versus $\Delta \mathrm{NO}_{3}^{-}$for June 2003 (c) and for August 2004 (d). For (c), the linear regression relationships (dashed lines) for both LSiLN, and HSiLN data. For (d), the linear regression relationship for LSiLN data (dashed line) and the linear regression relationship for all data (the solid line). Legends for (a, c) are the same as in Fig. 4 and legends for $(\mathbf{b}, \mathbf{d})$ are the same as in Fig. 5.

\subsection{The role of salt marshes and bays}

We considered the possibility of a mars and bay influence by examining $\mathrm{Si}: \mathrm{NO}_{3}^{-}$patterns in relationship to proximity to Barataria Bay. The marshes and bays could export dissolved $\mathrm{Si}$ (Struyf et al., 2006) and import $\mathrm{NO}_{3}^{-}$(Cai et al., 2000; Gribsholt et al., 2006; Das et al., 2010), and thus could show high $\mathrm{Si}: \mathrm{NO}_{3}^{-}$ratios in the waters from the marshes (Ren et al., 2009; Struyf et al., 2011) in contrast to a low $\mathrm{Si}: \mathrm{NO}_{3}^{-}$ ratio $(\approx 1)$ from the Mississippi River (Turner and Rabalais, 2004; Lohrenz et al., 1999). We found that shelf waters close to Barataria Bay had high Si concentrations and low $\mathrm{NO}_{3}^{-}$ concentrations, especially in June 2003 (Figs. 4 and 5), and we speculate that this was due to net export from the bay, a phenomenon that might be expected for a coastal ecosystem experiencing wetland loss (Ren et al., 2009). In the same cruise, Dagg et al. (2008) also found that particulate organic carbon and nitrogen, Chl-a, and TSM (total suspended material) were high in the northern Louisiana Bight and argued that the particulate materials were representative of output from Barataria Bay, consistent with physical characterizations of exchange processes in this system (Das et al., 2010; Li et al., 2011).

In addition, low diatom abundance was observed at locations coinciding with our HSiLN stations during the same cruise in 2003 (Dagg et al., 2008). This was consistent with a reduced utilization of Si by a non-diatom dominated population. Therefore, the degree to which elemental stoichiometry might reflect inputs from the extensive intertidal marshes or reduced Si utilization needs further investigation. However, it is apparent that the Mississippi River exported inorganic nutrients and their uptakes in the plume are the dominant processes in this complex coastal system.

\section{Summary and implications}

The biogeochemical processes in the Mississippi River plume and the adjacent coastal waters exhibited considerable spatial heterogeneity, with evidence of strong biological removal of carbon and nutrients in mid-salinity waters. The latter was especially true in June 2003. Relationships between DIC and nutrients were also strongly dependent on salinity and geographic location.

The stoichiometry of carbon and nutrient uptake in the Mississippi River plume was affected by multiple biogeochemical processes. Slopes of $\triangle \mathrm{DIC}$ versus $\Delta \mathrm{NO}_{3}^{-}$were largely dominated by net biological removal. Slopes of $\triangle \mathrm{DIC}$ versus $\triangle \mathrm{PO}_{4}^{3-}$ were also likely affected by additional $\mathrm{PO}_{4}^{3-}$ sources, including remineralization of organic forms of $\mathrm{P}$ and release from suspended particulates (Chambers et al., 1995). The slopes of $\Delta \mathrm{DIC}$ versus $\Delta \mathrm{Si}$ were influenced by a localized input of high $\mathrm{Si}$ and low $\mathrm{NO}_{3}^{-}$water from adjacent wetlands or the preferential removal of nitrogen. Provided that these non-Redfield processes are excluded from analysis, our results show general agreement with Redfieldtype $\mathrm{C} / \mathrm{N} / \mathrm{Si}$ ratios for predicting the net biological uptake relationships of DIC to inorganic $\mathrm{N}$ and $\mathrm{Si}$. These findings have implications for applications to biogeochemical models of large river plumes. 
Acknowledgements. We are grateful to M. Dagg for leading these two cruises and sharing data. The cooperation of the captains and the crews of R/V Pelican are gratefully acknowledged. We would like to acknowledge P. L. Yager for valuable comments and discussion. We thank G. Han for technical assistance. This study was funded by NSF (OCE-0752110 and OCE-0752254), NASA (NNX10AU06G), and NOAA (through the Northern Gulf Institute).

Edited by: S. W. A. Naqvi

\section{References}

Anderson, L. A. and Sarmiento, J. L.: Redfield ratios of remineralization determined by nutrient data analysis, Global Biogeochem. Cy., 8, 65-80, doi:10.1029/93gb03318, 1994.

Ammerman, J. W. and Glover, W. B.: Continuous underway measurement of microbial ectoenzyme activities in aquatic ecosystems, Mar. Ecol. Prog. Ser., 201, 1-12, doi:10.3354/meps201001, 2000.

Bates, N. R., Hansell, D. A., Carlson, C. A., and Gordon, L. I.: Distribution of $\mathrm{CO}_{2}$ species, estimates of net community production, and air-sea $\mathrm{CO}_{2}$ exchange in the Ross Sea polynya, J. Geophys. Res., 103, 2883-2896, doi:10.1029/97jc02473, 1998.

Borges, A. V. and Gypens, N.: Carbonate chemistry in the coastal zone responds more strongly to eutrophication than to ocean acidification, Limnol. Oceanogr., 55, 346-353, doi:10.4319/lo.2010.55.1.0346, 2010.

Brewer, P. G. and Goldman, J. C.: Alkalinity changes generated by phytoplankton growth, Limnol. Oceanogr., 21, 108-117, 1976.

Brzezinski, M. A.: The Si : C:N ratio of marine diatoms: interspecific variability and the effect of some environmental variables, J. Phycol., 21, 347-357, 1985.

Cai, W.-J.: Riverine inorganic carbon flux and rate of biological uptake in the Mississippi River plume, Geophys. Res. Lett., 30, 1032, doi:10.1029/2002GL016312, 2003.

Cai, W.-J. and Wang, Y.: The chemistry, fluxes, and sources of carbon dioxide in the estuarine waters of the Satilla and Altamaha rivers, Georgia, Limnol. Oceanogr., 43, 657-668, doi:10.4319/lo.1998.43.4.0657, 1998.

Cai, W.-J., Wiebe, W. J., Wang, Y., and Sheldon, J. E.: Intertidal marsh as a source of dissolved inorganic carbon and a sink of nitrate in the Satilla river-estuarine complex in the southeastern U.S., Limnol. Oceanogr., 45, 1743-1752, doi:10.4319/lo.2000.45.8.1743, 2000.

Cai, W.-J., Guo, X., Chen, C.-T. A., Dai, M., Zhang, L., Zhai, W., Lohrenz, S. E., Yin, K., Harrison, P. J., and Wang, Y.: A comparative overview of weathering intensity and $\mathrm{HCO}_{3}^{-}$flux in the world's major rivers with emphasis on the Changjiang, Huanghe, Zhujiang (Pearl) and Mississippi rivers, Cont. Shelf Res., 28, 1538-1549, doi:10.1016/j.csr.2007.10.014, 2008.

Cai, W.-J., Hu, X., Huang, W.-J., Jiang, L.-Q., Wang, Y., Peng, T.-H., and Zhang, X.: Alkalinity distribution in the Western North Atlantic Ocean margins, J. Geophys. Res., 115, C08014, doi:10.1029/2009jc005482, 2010.

Chambers, R., Fourqurean, J., Hollibaugh, J., and Vink, S.: Importance of terrestrially-derived, particulate phosphorus to phosphorus dynamics in a west coast estuary, Estuaries Coasts, 18, 518526, doi:10.2307/1352369, 1995.
Dagg, M. J. and Breed, G. A.: Biological effects of mississippi river nitrogen on the northern Gulf of Mexico - a review and synthesis, J. Marine Syst., 43, 133-152, doi:10.1016/j.jmarsys.2003.09.002, 2003.

Dagg, M., Bianchi, T., Breed, G., Cai, W., Duan, S., Liu, H., McKee, B., Powell, R., and Stewart, C.: Biogeochemical characteristics of the lower Mississippi River, USA, during June 2003, Estuaries Coasts, 28, 664-674, 2005.

Dagg, M., Ammerman, J., Amon, R., Gardner, W., Green, R., and Lohrenz, S.: A review of water column processes influencing hypoxia in the northern Gulf of Mexico, Estuaries Coasts, 30, 735752, 2007.

Dagg, M. J., Bianchi, T., McKee, B., and Powell, R.: Fates of dissolved and particulate materials from the Mississippi River immediately after discharge into the northern Gulf of Mexico, USA, during a period of low wind stress, Cont. Shelf Res., 28, 14431450, 2008.

Das, A., Justic, D., and Swenson, E.: Modeling estuarine-shelf exchanges in a deltaic estuary: implications for coastal carbon budgets and hypoxia, Ecol. Model., 221, 978-985, 2010.

DeMaster, D. J. and Pope, R. H.: Nutrient dynamics in Amazon shelf waters: results from AMASSEDS, Cont. Shelf Res., 16, 263-289, 1996.

Donald, K. M., Joint, I., Rees, A. P., Malcolm, S., Woodward, E., and Savidge, G.: Uptake of carbon, nitrogen and phosphorus by phytoplankton along the $20^{\circ} \mathrm{W}$ meridian in the NE Atlantic between $57.5^{\circ} \mathrm{N}$ and $37^{\circ} \mathrm{N}$, Deep-Sea Res. Pt. II, 48, 873-897, doi:10.1016/s0967-0645(00)00102-8, 2001.

Fennel, K., Hetland, R., Feng, Y., and DiMarco, S.: A coupled physical-biological model of the Northern Gulf of Mexico shelf: model description, validation and analysis of phytoplankton variability, Biogeosciences, 8, 1881-1899, doi:10.5194/bg-8-18812011, 2011.

Fisher, T. R., Harding, L. W., Stanley, D. W., and Ward, L. G.: Phytoplankton, nutrients, and turbidity in the Chesapeake, Delaware, and Hudson estuaries, Estuar. Coast. Shelf S., 27, 61-93, 1988.

Frigstad, H., Andersen, T., Hessen, D. O., Naustvoll, L.-J., Johnsen, T. M., and Bellerby, R. G. J.: Seasonal variation in marine $\mathrm{C}: \mathrm{N}: \mathrm{P}$ stoichiometry: can the composition of seston explain stable Redfield ratios?, Biogeosciences, 8, 2917-2933, doi:10.5194/bg-8-2917-2011, 2011.

Gazeau, F., Gattuso, J.-P., Middelburg, J., Brion, N., Schiettecatte, L.-S., Frankignoulle, M., and Borges, A.: Planktonic and whole system metabolism in a nutrient-rich estuary (the Scheldt estuary), Estuaries Coasts, 28, 868-883, doi:10.1007/bf02696016, 2005.

Geider, R. and La Roche, J.: Redfield revisited: Variability of $\mathrm{C}: \mathrm{N}: \mathrm{P}$ in marine microalgae and its biochemical basis, Eur. J. Phycol., 37, 1-17, doi:10.1017/s0967026201003456, 2002.

Green, R. E., Bianchi, T. S., Dagg, M. J., Walker, N. D., and Breed, G. A.: An organic carbon budget for the Mississippi River turbidity plume and plume contributions to air-sea $\mathrm{CO}_{2}$ fluxes and bottom water hypoxia, Estuaries Coasts, 29, 579-597, doi:10.1007/bf02784284, 2006.

Green, R. E., Breed, G. A., Dagg, M. J., and Lohrenz, S. E.: Modeling the response of primary production and sedimetation to variable nitrate loading in the Mississippi River plume, Cont. Shelf Res., 28, 1451-1465, 2008. 
Gribsholt, B., Struyf, E., Tramper, A., Andersson, M., Brion, N., De Brabandere, L., Van Damme, S., Meire, P., Middelburg, J., Dehairs, F., and Boschker, H.: Ammonium Transformation in a Nitrogen-Rich Tidal Freshwater Marsh, Biogeochemistry, 80, 289-298, doi:10.1007/s10533-006-9024-8, 2006.

Guo, X., Cai, W.-J., Huang, W.-J., Wang, Y., Chen, F., Murrell, M. C., Lohrenz, S. E., Jiang, L.-Q., Dai, M., Hartmann, J., Lin, Q., and Culp, R.: Carbon dynamics and community production in the Mississippi River plume, Limnol. Oceanogr., 57, 1-17, doi:10.4319/lo.2012.57.1.0001, 2012.

Gypens, N., Lancelot, C., and Borges, A. V.: Carbon dynamics and $\mathrm{CO}_{2}$ air-sea exchanges in the eutrophied coastal waters of the Southern Bight of the North Sea: a modelling study, Biogeosciences, 1, 147-157, doi:10.5194/bg-1-147-2004, 2004.

Hecky, R. E., Campbell, P., and Hendzel, L. L.: The stoichiometry of carbon, nitrogen, and phosphorus in particulate matter of lakes and oceans, Limnol. Oceanogr., 38, 709-724 1993.

Hopkinson, C. S. and Vallino, J. J.: Efficient export of carbon to the deep ocean through dissolved organic matter, Nature, 433, 142145, 2005.

Hupe, A. and Karstensen, J.: Redfield stoichiometry in Arabian Sea subsurface waters, Global Biogeochem. Cy., 14, 357-372, doi:10.1029/1999gb900077, 2000.

Lawson, C. L. and Hanson, R. J.: Solving Least Squares Problems, Prentice-Hall, Chapter 23, 161 pp., 1974.

Li, Y.-H. and Peng, T.-H.: Latitudinal change of remineralization ratios in the oceans and its implication for nutrient cycles, Global Biogeochem. Cy., 16, 1130, doi:10.1029/2001gb001828, 2002.

Li, Y.-H., Karl, D. M., Winn, C. D., Mackenzie, F. T., and Gans, K.: Remineralization ratios in the subtropical North Pacific gyre, Aquat. Geochem., 6, 65-85, 2000.

Li, C., White, J. R., Chen, C., Lin, H., Weeks, E., Galvan, K., and Bargu, S.: Summertime tidal flushing of Barataria Bay: transports of water and suspended sediments, J. Geophys. Res., 116, C04009, doi:10.1029/2010jc006566, 2011.

Lohrenz, S. E., Dagg, M. J., and Whitledge, T. E.: Enhanced primary production at the plume/oceanic interface of the Mississippi River, Cont. Shelf Res., 10, 639-664, 1990.

Lohrenz, S. E., Fahnenstiel, G. L., Redalje, D. G., Lang, G. A., Chen, X., and Dagg, M. J.: Variations in primary production of northern Gulf of Mexico continental shelf waters linked to nutrient inputs from the Mississippi River, Mar. Ecol. Prog. Ser., 155, 45-54, doi:10.3354/meps155045, 1997.

Lohrenz, S. E., Fahnenstiel, G. L., Redalje, D. G., Lang, G. A., Dagg, M. J., Whitledge, T. E., and Dortch, Q.: Nutrients, irradiance, and mixing as factors regulating primary production in coastal waters impacted by the Mississippi River plume, Cont. Shelf Res., 19, 1113-1141, 1999.

Morey, S. L., Martin, P. J., O’Brien, J. J., Wallcraft, A. A., and Zavala-Hidalgo, J.: Export pathways for river discharged fresh water in the northern Gulf of Mexico, J. Geophys. Res., 108, 3303, doi:10.1029/2002jc001674, 2003.
Pahlow, M. and Riebesell, U.: Temporal trends in deep ocean Redfield ratios, Science, 287, 831-833, doi:10.1126/science.287.5454.831, 2000.

Redfield, A. C.: The biological control of chemical factors in the environment, Am. Sci., 46, 205-221, 1958.

Redalje, D. and Fahnenstiel, G.: The relationship between primary production and the vertical export of particulate organic matter in a river-impacted coastal ecosystem, Estuaries Coasts, 17, 829838, doi:10.2307/1352751, 1994.

Ren, L., Rabalais, N. N., Turner, R. E., Morrison, W., and Mendenhall, W.: Nutrient limitation on phytoplankton growth in the upper Barataria Basin, Louisiana: microcosm bioassays, Estuaries Coasts, 32, 958-974, 2009.

Struyf, E., Dausse, A., Van Damme, S., Bal, K., Gribsholt, B., Boschker, H. T. S., Middelburg, J. J., and Meire, P.: Tidal marshes and biogenic silica recycling at the land-sea interface, Limnol. Oceanogr., 51, 838-846, doi:10.4319/lo.2006.51.2.0838, 2006.

Struyf, E., Gribsholt, B., Boschker, E., Dehairs, F., and Meire, P.: N and $\mathrm{Si}$ cycling in freshwater tidal marshes, in: Aspects of coastal research in contribution to LOICZ in the Netherlands and Flanders (2002-2010), edited by: Heip, C. and Laane, R., Geesthacht: Helmholtz-Zentrum, 155-161, 2011.

Sylvan, J. B., Quigg, A., Tozzi, S., and Ammerman, J. W.: Eutrophication-induced phosphorus limitation in the Mississippi River plume: Evidence from fast repetition rate fluorometry, Limnol. Oceanogr., 52, 2679-2685, doi:10.4319/lo.2007.52.6.2679, 2007.

Takahashi, T., Broecker, W. S., and Langer, S.: Redfield ratio based on chemical data from isopycnal surfaces, J. Geophys. Res., 90, 6907-6924, doi:10.1029/JC090iC04p06907, 1985.

Ternon, J. F., Oudot, C., Dessier, A., and Diverres, D.: A seasonal tropical sink for atmospheric $\mathrm{CO}_{2}$ in the Atlantic Ocean: the role of the Amazon River discharge, Mar. Chem., 68, 183-201, 2000.

Turner, R. E. and Rabalais, N. N.: Suspended Sediment, C, N, P, and Si Yields from the Mississippi River Basin, Hydrobiologia, 511, 79-89, doi:10.1023/B:HYDR.0000014031.12067.1a, 2004.

van Heerden, I. L., Wells, J. T., and Roberts, H. H.: River-dominated suspended-sediment deposition in a new Mississippi Delta, Can. J. Fish. Aquat. Sci., 40, 60-71, 1983.

Walker, N. D., Wiseman, W. J., Rouse, L. J., and Babin, A.: Effects of river discharge, wind stress, and slope eddies on circulation and the satellite-observed structure of the Mississippi River plume, J. Coastal Res., 21, 1228-1244, doi:10.2112/04-0347.1, 2005.

Wolf-Gladrow, D. A., Zeebe, R. E., Klaas, C., Körtzinger, A., and Dickson, A. G.: Total alkalinity: the explicit conservative expression and its application to biogeochemical processes, Mar. Chem., 106, 287-300, 2007.

York, D.: Least-squares fitting of a straight line, Can. J. Phys., 44, 1079-1086, doi:10.1139/p66-090, 1966. 